\title{
Growth and Physiological Responses of Salak Cultivars (Salacca zalacca (Gaertn.) Voss) to Different Growing Media
}

\author{
Reni Lestari (Corresponding author) \\ Center for Plant Conservation Bogor Botanic Gardens \\ The Indonesian Institute of Sciences, Jl. Ir. H. Djuanda 13, Bogor 16003, Indonesia \\ Tel: 62-813-1745-8626 E-mail: reni_naa@yahoo.com
}

Georg Ebert

Head of Research and Development, COMPO GmbH \& Co KG

Gildenstraße 3848157 Muenster, Germany

Tel: 49-176-1234-9315 E-mail: georg.ebert@compo.de

Susanne Huyskens-Keil

Head of Research Group Quality Dynamics and Postharvest Physiology

Division Urban Plant Ecophysiology, Humboldt Universität zu Berlin

Unter den Linden 6, 10099 Berlin, Germany

Tel: 49-30-3147-1262Ｅ-mail: Susanne.huyskens@agrar.hu-berlin.de

Received: March 3, 2011 Accepted: March 24, 2011 Published: December 1, 2011

doi:10.5539/jas.v3n4p261 URL: http://dx.doi.org/10.5539/jas.v3n4p261

The research was financed by the German Academic Exchange Services (DAAD), Germany.

\begin{abstract}
The study to investigate growth and physiological responses of salak cultivars to different growing media was carried out in a greenhouse of the Institute for Horticultural Sciences, Department of Fruit Sciences of Humboldt University Berlin at Berlin. The temperature inside the greenhouse were adjusted to $20^{\circ} \mathrm{C} / 25^{\circ} \mathrm{C}$ (day/night) and the relative humidity varied between $20 \%$ and $70 \%$. Pure quartz sand, peat and a sand/compost mixture were tested as growth substance. The following parameters were measured: shoot dry weight, root dry weight, shoot length increment, leaf area increment, net $\mathrm{CO}_{2}$ assimilation rate $\left(\mathrm{P}_{\mathrm{N}}\right)$, leaf colour and plant mineral contents $(\mathrm{N}, \mathrm{P}$, $\mathrm{K}, \mathrm{Ca}$ and $\mathrm{Mg}$ ). Quartz sand, supplied with a complete nutrition solution was the best growing medium, whereas low $\mathrm{pH}$ peat was not suitable for salak seedlings due to the inhibitory growth effect. "Pondoh hitam" was the most vigorous cultivar.
\end{abstract}

Keywords: Salacca zalacca, Growing media, Sand, Peat, Compost, Physiological responses

\section{Introduction}

Indonesia has many options for the development of its horticultural industry, such as intensive plantation systems, year-round production and high quality fruits (Winarno, 1997). Therefore, the development of the horticultural sector including fruit production has priorities such as in choosing suitable commodities for certain areas and the promotion of fruit production. Salak (Salacca zalacca (Gaertn.) is one of the most important fruit species in Indonesia and has been included in the country's fruit priority list.

In Indonesia, salak palms are cultivated throughout the islands and the fruit is widely used as fresh fruit. Salak production in Indonesia has increased from $423.5 \mathrm{t}$ in 2000 to $862.5 \mathrm{t}$ in 2009 (Ministry of Agriculture, 2011). Fresh salak fruits have been exported to Singapore, Middle-East, Malaysia, Hongkong and China (Ministry of Agriculture, 2009). There are 30 cultivars of salak, which distribute across the Indonesian islands (Sudaryono et al., 1993; Kusumo, 1995). The availability of superior quality fruit from selected cultivars, such as "pondoh" from 
Yogyakarta and "gula pasir" from Bali. "Pondoh" is cultivated in the sub district Sleman of the Yogyakarta province.

Salak fruits are more or less of a round shape, $2.5-10 \mathrm{~cm} \times 5-8 \mathrm{~cm}$ in diameter. The fruit develops in tight, globose bunches. They are covered with regularly arranged scales originating from the peel of the fruit (pericarp) giving the fruit the appearance of a snake skin. The aromatic fruits enclose a soft, transculent pulp with a taste comparable to a combination of apple, pineaple and banana (Schuiling and Mogea, 1992). Fruits contain 1 to 3 blackish seeds, which are about $1 \mathrm{~cm}$ in diameter (Ochse, 1931). Salak palm trees are only 1.5 to $5 \mathrm{~m}$ high, extremely spiny, leaves develop from the ground level. Salak is a typical under-storey plant growing in the low lands of tropical rain forests in Indonesia and other Southeast Asian countries.

In 1991, some important new salak plantations have been settled in Riau (Sumatera island) and in Kalimantan (Winarno, 1997). In the new production areas, suitable site conditions for salak palms such as peat-land still have to be found without neglecting the quality of the fruit.

Wetlands cover an area of 17 to 27 million ha of Indonesia, which are distributed over Sumatera, Kalimantan, Sulawesi and Irian Jaya (Wetlands International, 2003). Only 5.6 million ha can be used for agricultural purposes. However, the development of the agricultural sector is very fast. Therefore, the possibility of using peat land for horticultural purposes such as for salak is an interesting point. A study showed that a mixture of peat/rice hull (2/1, v/v) was suitable as growing medium for salak "pondoh" seedlings (Kusmiba, 1994). In industrialised countries, peat alone or mixed with other organic and inorganic substances, is one of the most important materials for the preparation of pot plant substrates (Cattivello et al., 1997).

Peat is a mixture of partially decomposed plants, microbes and their transformation products, which grow in swampy conditions. The water holding ability of peat is high, but aeration in containers may be poor (Handreck and Black, 1999). Tropical peat soil has a low mineral content, a low $\mathrm{pH}(<4)$ but about $90 \%$ of organic matter (Andriesse, 1988). The content of nitrogen is very low due to the high $\mathrm{C} / \mathrm{N}$ ratio. Micro-nutrients such as $\mathrm{Cu}, \mathrm{B}$ and $\mathrm{Zn}$ are also absent in organic soils.

Compost is another growing substrate usually used in horticulture, which results from controlled decomposition of organic matter to a point where the product can be used as a soil amendment to improve crop productivity. The low concentration of nutrients in compost, particularly $\mathrm{N}$ and $\mathrm{K}$, may cause a poor plant growth. Therefore, fertilisers are usually added to compost (Chaney et al., 1980). High organic matter content, porosity, good aeration and drainage characteristics are some of the benefits of compost (Pinamonti and Sicher, 2000). However, some negative aspects such as physiological disorders of crop plants, eutrophication of the ground water and nutrient losses from the substrate should also be considered (Pinamonti and Sicher, 2000).

Sand culture in combination with the use of nutrient solutions has been used in horticultural production since the $19^{\text {th }}$ century (Hewitt, 1952). Quartz sand (grain size $1.2 \mathrm{~mm}$, low in calcium carbonate (limestone) content), allows good aeration of plant roots and it retains sufficient moisture (Ellis and Swaney, 1938)

In order to promote the production and the fruit quality of salak, knowledge about eco-physiological properties of the species is crucial important. However, only a few investigations on these aspects have been conducted so far. Therefore, this study was devoted to investigate growth and physiological responses of some salak cultivars to different plant growing media.

\section{Material and Methods}

\subsection{Location and experimental design}

The study was carried out for a period of 14 weeks (Nov 2002 - Feb 2003) in a greenhouse of the Institute for Horticultural Sciences, Department of Fruit Sciences of Humboldt University Berlin in Berlin. The temperature inside the greenhouse were adjusted to $20^{\circ} \mathrm{C} / 25^{\circ} \mathrm{C}$ (day/night) and the relative humidity varied between $20 \%$ and $70 \%$. Light period was $12 \mathrm{~h}$, additional light was provided by mercury lamps (HQI-TS/D, $400 \mathrm{~W}$, OSRAM, Germany).

A total of 84 plants was arranged in a complete block design. Four-months-old seedlings of 4 different salak cultivars were used, i.e. "gading" (G), "pondoh super" (PS), "pondoh hitam" (PH) and "pondoh manggala" (PM). Three types of plant growing media were tested: 1 . Pure quartz sand 0.6 to $1.2 \mathrm{~mm}(\mathrm{~S}), 2$. peat $(\mathrm{P})$ and 3 . sand/compost mixture (SC; $1 / 1$, weight/weight). Peat medium consisted of $95 \%$ to $98 \%$ organic matter with $\mathrm{H} 3-$ $\mathrm{H} 5$ degree of decomposition and $\mathrm{pH}$ 3. The compost medium ( $\mathrm{pH}$ 6) comprised of $320 \mathrm{~g} / \mathrm{l} \mathrm{N}, 320 \mathrm{~g} / 1 \mathrm{P}_{2} \mathrm{O}_{5}, 450$ $\mathrm{mg} / 1 \mathrm{~K}_{2} \mathrm{O}$ and $<3 \mathrm{~g} / \mathrm{l} \mathrm{NaCl}$. Media and cultivars were arranged in 12 combinations: S-G, S-PS, S-PH, S-PM; P-G, P-PS, P-PH, P-PM; SC-G, SC-PS, SC-PH and SC-PM. 
After germination, seedlings were transplanted in $14.5 \mathrm{~cm} \mathrm{x} 11 \mathrm{~cm}$ pots, filled with growing medium according to the treatments listed above and were watered daily $(100 \mathrm{ml} / \mathrm{plant})$ with a complete nutrition solution (Manna Lina Spezial 24-5-11 (3), Wilhelm Hang, Germany), prepared with distilled water. The nutrition solution contained $24 \% \mathrm{~N}, 5 \% \mathrm{P}_{2} \mathrm{O}_{5}, 11 \% \mathrm{~K}_{2} \mathrm{O}, 3 \% \mathrm{MgO}, 0.05 \% \mathrm{Fe}, 0.05 \% \mathrm{Mn}, 0.005 \% \mathrm{Zn}, 0.02 \% \mathrm{Cu}, 0.01 \% \mathrm{~B}$ and $0.002 \%$ Mo.

The following parameters were measured: shoot dry weight, root dry weight, shoot length increment, leaf area increment, net $\mathrm{CO}_{2}$ assimilation rate $\left(\mathrm{P}_{\mathrm{N}}\right)$, leaf colour and plant mineral contents $(\mathrm{N}, \mathrm{P}, \mathrm{K}, \mathrm{Ca}$ and $\mathrm{Mg})$.

\subsection{Growth}

Shoot and root dry weight were measured at the end of the experiment after drying the fresh samples at $103^{\circ} \mathrm{C}$ to constant weight (Maier, 1990). Leaf samples were weighed after drying at $65^{\circ} \mathrm{C}$ for $8 \mathrm{~h}$ and were later used for the analysis of mineral contents. Shoot length and leaf area were first measured immediately after the seedlings had been transplanted. The second measurement was 14 weeks later. Shoot length was measured with a ruler, leaf area was measured with a leaf area meter (CI - 202, CID Inc., USA).

\section{$2.3 \mathrm{Net} \mathrm{CO}_{2}$ assimilation rate}

Net $\mathrm{CO}_{2}$ assimilation rate $\left(\mathrm{P}_{\mathrm{N}}\right)$ of seedling leaves was assessed 6, 8 and 13 weeks after the onset of the experiment using a portable photosynthesis system (CI-301PS, CID Inc., USA). A $400 \mathrm{~W}$ lamp (HQI-TS/D, OSRAM, Germany) was used to provide additional light during the gas exchange measurements (starting from 10 am until 1 $\mathrm{pm})$. Before the measurement, plants were exposed to the high irradiation for about $1 \mathrm{~h}$ for adaptation to a photon flux density of 500 to $800 \mu \mathrm{mol} \mathrm{m} \mathrm{m}^{-1}$.

\subsection{Leaf colour}

The measurement of leaf colour was conducted using a Minolta Colorimeter (CR-321, Minolta, Japan) with a standardised light type D65. The equipment was calibrated with a white standard plate. Colour measurement were expressed in the $\mathrm{L}^{*} \mathrm{a} * \mathrm{~b} *$ scale (McGuire, 1992).

\subsection{Mineral content}

Leaf mineral contents were analysed from dried and ground samples (Mikro-Feinmühle-Cullati DCFH 48, Janke \& Kunkel, Germany). N content was determined following a modified Kjeldahl method as has been described by Okoye (1980). 500 mg leaf powder were digested (Büchi 430 Digestor, Büchi Labortechnik AG, Switzerland) in boiling $98 \% \mathrm{H}_{2} \mathrm{SO}_{4}(20 \mathrm{ml})$ and selenium catalyst (15348 Merck, Germany). The samples were thereafter distilled in a Büchi-Scrubber B-412 (Büchi Labortechnik AG, Switzerland) into $0.1 \mathrm{~mol} \mathrm{H}_{3} \mathrm{BO}_{4}$ and were subsequently titrated with $0.1 \mathrm{~N} \mathrm{HCl}$.

$\mathrm{P}, \mathrm{Ca}, \mathrm{Mg}$ and $\mathrm{K}$ were analysed according to a method described by Evenhuis and de Waard (1980). The samples were dry-ashed at $490{ }^{\circ} \mathrm{C}$ for $4 \mathrm{~h}$. Ashes were dissolved in $25 \% \mathrm{HCl}$ and were evaporated in a sand bath for $20 \mathrm{~min}$ until the complete disappearance of solid residues. P was determined photometrically (Eppendorf $1101 \mathrm{M}$, Germany). The other minerals were analysed using atomic absorption spectophotometry (905 A, GBC, Australia). Mineral contents were calculated as mg/g DM.

\subsection{Statistical analyses}

All sample data were subjected to compare means and further analysed with least significant difference (LSD) test (Steel et al., 1997), with significant difference of $\mathrm{p} \leq 0.05$ between means using the Statistic Program MINITAB 14 (Minitab Inc., State College, USA, 2001).

\section{Results and Discussions}

\subsection{Growth}

The seedling age in this study (four months after germination) is representative for the establishing conditions in the nursery before the plants are transferred to the orchard. Growth parameters of different salak cultivars are presented in Figure 1 and Table 1. Among the different salak cultivars, only small differences in the growth parameters were found. "Pondoh hitam" showed a stronger shoot growth than the other cultivars (19\% to $48 \%)$. Leaf growth increment of "pondoh hitam" and "pondoh manggala" cultivars was higher as compared with that of "gading" and "pondoh super".

The influence of different media on growth parameters of salak seedlings are summarised in Figure 2 and Table 2. Seedlings growing on peat had a lower root dry weight than those growing in sand or in sand/compost, respectively (Figures 2 and 3). The shoot/root ratio of peat-grown seedlings was higher as compared to that of the other variants. 
On the other hand, leaf area and shoot length increment of salak growing in sand/compost was lower as in seedlings grown in sand or in peat.

The effects of cultivar and growing media on growth of salak seedlings are presented in Table 3. There was a slight reduction in root growth of salak cultivars growing in peat (Figure 3). On the other hand, "pondoh hitam" was found to have the most vigorous root and shoot growth in all growing media tested. "Pondoh super" seedlings growing in peat were found to have the lowest root and shoot dry weight. The tendency of higher shoot/root ratio was found in all salak cultivars growing in peat. Leaf area and shoot length increment of "pondoh hitam" were higher in all media tested as compared with the other cultivars. "Pondoh manggala" grown in sand/compost developed the smallest leaves and shoot length increments.

Growth data indicated that "pondoh hitam" seems to be the most vigorous cultivar, since the growing conditions were same for all cultivars tested. Many experimental studies revealed that plants show genetically controlled differences in dry matter production (Grime and Campbell, 1991). On the other hand, the results of the effect of growing media on growth showed that sand was the best medium for salak seedlings. Sand enables a good aeration for the roots and a high availability of nutrients. The low $\mathrm{pH}$ of peat induced a decrease of root growth and an increase in shoot/root ratio in salak plants. Inhibition of root elongation at $\mathrm{pH}$ values below 5 is a common feature in many plant species and is caused by various factors, such as impairment of $\mathrm{H}^{+}$efflux from roots (Schubert et al., 1990). According to Marschner (1995), $\mathrm{pH}$ effects on cation uptake are in accordance with the key role of the plasma membrane-bound proton efflux pump as the driving force for ion uptake. At high substrate $\mathrm{H}^{+}$ concentration, the efficiency of the $\mathrm{H}^{+}$efflux pump decreases whereas the downhill transport of $\mathrm{H}^{+}$from the apoplasm into the cytoplasm is enhanced. Electro potential of root cells decreases from $-150 \mathrm{mV}$ at $\mathrm{pH} 6$ to $-100 \mathrm{mV}$ at $\mathrm{pH} 4$ (Dunlop and Bowling, 1978).

On the other hand, some possible changes in physical and chemical characteristics during aging of compost media possibly might have reduced leaf area and shoot length of salak seedlings. Some composts have been reported to have satisfactory pore space at the beginning of the period, but undergo compaction during the further growth period of the plants (Fitzpatrick, 2002). Moreover, according to Handreck and Black (1999), high moisture conditions of composts supplemented with fertilisers will cause continuous decomposition. The compost may become anaerobic at low $\mathrm{pH}$ or harmful compounds such as organic acids will accumulate. The results of this study concerning interaction of cultivar and growing media indicated that "pondoh hitam" was tolerant to all growing media tested. On the other hand, higher susceptibility of "pondoh super" to peat rather than the other media tested was found. Cattivello et al. (1997) reported that different kind of peat media and plant species significantly influenced growth parameters and the final quality of Cyclamen persicum and Euphorbia pulcherrima.

\section{$3.2 \mathrm{Net} \mathrm{CO}_{2}$ assimilation rate}

The net $\mathrm{CO}_{2}$ assimilation rate $\left(\mathrm{P}_{\mathrm{N}}\right)$ of different salak cultivars is presented in Figure $4 . \mathrm{P}_{\mathrm{N}}$ of all cultivars increased from week 6 to week 13 after transplanting. "Gading" exhibited the highest $\mathrm{P}_{\mathrm{N}}$ of all cultivars tested. $\mathrm{P}_{\mathrm{N}}$ of "gading" at week 6 was up to $100 \%$ higher than, whereas at week 13 was up to $35 \%$ higher than $\mathrm{P}_{\mathrm{N}}$ of the other cultivars.

The effect of growing media on $\mathrm{P}_{\mathrm{N}}$ of seedlings is summarised in Figure $5 . \mathrm{P}_{\mathrm{N}}$ of salak seedlings growing in peat and in sand/compost was higher than $\mathrm{P}_{\mathrm{N}}$ of the other cultivars.

The interactive effect of salak cultivars and growing media on $\mathrm{P}_{\mathrm{N}}$ is presented in Table $4 . \mathrm{P}_{\mathrm{N}}$ results reflected a higher $\mathrm{P}_{\mathrm{N}}$ of "gading" in all growing media tested as compared with the other cultivars. It seems that the genotype has a stronger effect on $\mathrm{P}_{\mathrm{N}}$ than the growth substrate especially at an early developmental stage. This result is consistent with findings of Salisbury and Ross (1985). Differences in $\mathrm{P}_{\mathrm{N}}$ of the salak cultivars tested in this study can be explained by the fact that "gading" is genetically not closely related to the pondoh cultivars.

$\mathrm{P}_{\mathrm{N}}$ of salak plants is relatively low $\left(0.7\right.$ to $\left.4.5 \mu \mathrm{mol} \mathrm{CO} \mathrm{m}^{-2} \mathrm{~s}^{-1}\right)$ as compared to other tropical tree species, such as peach palm, Bactris gasipaes Kunth $\left(10.1 \mu \mathrm{mol} \mathrm{CO} \mathrm{m}^{-2} \mathrm{~s}^{-1}\right)$ (Oliveira et al., 2002), oil palm $\left(25 \mu \mathrm{mol} \mathrm{CO}_{2} \mathrm{~m}^{-2} \mathrm{~s}^{-1}\right)$ (Dufrene and Saugier, 1993), mango (5.9 to $9.6 \mu \mathrm{mol} \mathrm{CO}_{2} \mathrm{~m}^{-2} \mathrm{~s}^{-1}$ ) (Fukamachi et al., 1998) and banana (15 to 22 $\mu \mathrm{mol} \mathrm{CO} \mathrm{m}^{-2} \mathrm{~s}^{-1}$ ) (Thomas and Turner, 2001).

\subsection{Leaf colour}

Leaf colour can be used to determine the nutritional state of the plant (i.e. nutrient deficiency) (Marschner, 1995). Data on leaf colour of salak seedlings of different cultivars are presented in Table 5. No differences were found for $\mathrm{L}^{*}, \mathrm{a}^{*}, \mathrm{~b}^{*}$, chroma and hue angle values between the cultivars tested, indicating there was no cultivar effect on the leaf colour of salak seedlings. 
Data on leaf colour of seedlings grown in different growing media are summarised in Table 6. Foliar $\mathrm{L}^{*}, \mathrm{~b}^{*}$ and chroma values of seedlings growing in peat were significantly higher than of plants of the other variants, whereas $\mathrm{a}^{*}$ and hue angle values of seedlings growing in peat were lower as compared to sand and sand/compost. The data reflected also a darker green leaf colour of seedling grown in sand or sand/compost than in peat. In contrast, these results point out a more pronounced yellow leaf colour of seedlings growing in peat, which was possibly caused by nutrient imbalances.

\subsection{Mineral content}

The influence of growing media on mineral contents of salak seedlings is summarised in Table 7. Salak leaf mineral concentration was similar to those found in 4-months-old oil palm seedlings, i.e. 22 to $32 \mathrm{mg} / \mathrm{g} \mathrm{N}, 1.4$ to $2.1 \mathrm{mg} / \mathrm{g} \mathrm{P}, 12$ to $15 \mathrm{mg} / \mathrm{g} \mathrm{K}, 3$ to $5 \mathrm{mg} / \mathrm{g} \mathrm{Mg} 5$ to $6 \mathrm{mg} / \mathrm{g} \mathrm{Mg}$ (Ross, 1999). Mineral contents in leaves of salak seedlings growing in different media tested were in the optimal range, due to the supply of a balanced nutrient solution to the plants. $\mathrm{Mg}$ and $\mathrm{P}$ contents of salak seedlings growing in peat were higher in comparison seedlings growing on sand or sand/compost. A low $\mathrm{P}$ content of seedlings in sand/compost was observed. $\mathrm{N}, \mathrm{P}$ and $\mathrm{Mg}$ contents of seedlings in sand/compost were much lower, whereas $\mathrm{K}$ and $\mathrm{Ca}$ were higher than those of seedlings growing in sand or peat.

There was a considerable variation of foliar nutrient levels between the different treatments indicating a strong influenced of the growing medium on the nutrient uptake of the salak seedlings (Table 10). After Marschner (1995) the nutrient concentration in the soil or substrate solution is an important factors for the nutrient acquisition of the plant root. The nutrient concentration and availability vary widely depending on such factors as moisture, $\mathrm{pH}$, cation-exchange capacity, redox potential, quantity of organic matter, microbial activity and nutrient application (Asher, 1978). The higher Ca foliar content of seedlings growing in peat or in sand/compost indicated the better availability of $\mathrm{Ca}$ in these substrates, since there was no additional supply of $\mathrm{Ca}$ to salak plants during the experimental periods. Moreover, the availability of $\mathrm{Mg}$ and $\mathrm{P}$ in peat supplied with additional fertiliser was high, leading to luxurious content of these mineral in salak seedlings. In contrast, $\mathrm{N}, \mathrm{P}$ and $\mathrm{Mg}$ might have been fixed in the compost containing medium and became unavailable for plants due to the factors mentioned above Organic matter in the growing medium is able to fix considerable amounts of $\mathrm{NH}_{4}$ in non-exchangeable forms (Marschner, 1995). The competition among cations was possibly enhanced by the application of minerals, for example between $\mathrm{K}^{+}$and $\mathrm{NH}_{4}{ }^{+}$(Axley and Legg, 1960; Walsh and Murdoch, 1963). Competition in ion uptake by salak seedlings in growing media tested could also be a reason for the diverging of nutrient contents of the plants. This competition occurs particularly between ions with similar physicochemical properties such as valency and ion diameter (Marschner, 1995). $\mathrm{K}^{+}$and $\mathrm{Ca}^{+}$are regarded to compete quite effectively with $\mathrm{Mg}^{2+}$ (Schimansky, 1981).

$\mathrm{P}$ of seedlings growing in sand/compost was low, which was only $33 \%$ and $66 \%$ of the content in seedlings growing in peat and sand, respectively. The low P content can be correlated with growth and leaf colour, resulting in a leaf area reduction (14\% lower than seedlings in peat and $24 \%$ lower than those in sand) and a darker green colour of leaf, especially as compared with those growing in peat (Figure 2 and Table 6). On the other hand, the low P content did not affect root growth and shoot/root ratio of seedlings in sand/compost, especially as compared to seedlings growing in sand (Figure 2). These results are accordance to Fredeen et al. (1989), who reported that, root growth in soybean was less inhibited under P deficiency, leading to a typical decrease in shoot/root dry weight ratio.

\section{Concluding Remarks}

"Pondoh hitam" was the most vigorous salak cultivar tested on different growing media such as sand, peat and sand/compost mixture. In general, the optimal substrate for salak seedlings in our study was pure sand, supplied with a complete nutrition solution. Peat has a very low $\mathrm{pH}$ and was found to be less suitable as growing medium for salak seedlings.

It can be concluded from this study that salak seedlings should be raised in a sand-containing substrate ensuring a good aeration of the root zone rather than pure peat. The supply of nutrient to the growing medium promotes the vegetative growth of salak seedlings. This is an important factor for successful establishment of new salak plantations for commercial fruit production. Genetical differencies between salak varieties with respect to site conditions, i.e. type of soil and nutrient availability, have also to be considered.

\section{References}

Andriesse. (1988). Nature and management of tropical peat soils. FAO Soils Bulletin 59. Food and Agriculture Organisation of The United Nations, Rome, Italy. 
Asher, C.J. (1978). Natural and synthetic culture media for Spermatophytes. CRC Handb. Ser. Nutr. Food, Sect. G, 3, 575-609.

Axley, J.H. \& Legg, J.O. (1960). Ammonium fixation in soils and the influence of potassium on nitrogen availability from nitrate and ammonium sources. Soil. Sci., 90, 151-156. http://dx.doi.org/10.1097/00010694-196009000-00001

Cattivello, C., Della Donna, E. \& Pantanali, R. (1997). Behaviour of peat substrates during cyclamen and poinsettia cultivation. Acta Hort., 450, 439-447.

Chaney, R.L., Munns, J.B. \& Cathey, H.M. (1980). Effectiveness of digested sewage sludge compost in supplying nutrients for soilless potting media. J. Am. Soc. Hort. Sci., 105 (4), 485-492.

Dufrene, E. \& Saugier, B. (1993). Gas exchange of oil palm in relation to light, vapour pressure deficit, temperature and leaf age. Functional Ecol., 7, 97-104. http://dx.doi.org/10.2307/2389872

Dunlop, J. \& Bowling, D.J.F. (1978). Uptake of phosphate by white clover. II. The effect of $\mathrm{pH}$ on the electronic phosphate pump. J. Exp. Bot., 29, 1147 - 1153. http://dx.doi.org/10.1093/jxb/29.5.1147

Ellis, C. \& Swaney, M.W. (1938). Soilless growth of plants. Reinhold Publishing Corporation. New York, USA.

Evenhuis, B. \& de Waard, P.W.F. (1980). Principles and practices in plant analysis. FAO Soils Bulletin, 38 (1), 152-163.

Fitzpatrick, G.E. (2002). Compost utilization in ornamental and nursery crop production systems. In: Stofella, P.J. and Kahn, B.A. (eds). Compost utilization in horticultural cropping systems. Lewis Publishers, CRC Press LLC, Florida, USA.

Fredeen, A.L., Rao, I.M. \& Terry, N. (1989). Influence of phosphorous nutrition on growth and carbon partitioning in Glycine max. Plant. Physiol., 89, 225 - 230. http://dx.doi.org/10.1104/pp.89.1.225

Fukamachi, H., Yamada, M., Komori, S. \& Hidaka, T. (1998). Photosynthesis in longan and mango as influenced by high temperatures under high irradiance. JIRCAS Newsletter, No. 17.

Grime, J.P. \& Campbell, B.D. (1991). Growth rate, habitat productivity, and plant strategy as predictors of stress response. In: Mooney, H.A., Winner, W.E. and Pell, E.J. (eds.). Response of plant to multiple stresses. Academic Press. London, UK.

Handreck, K.A. \& Black, N.D. (1999). Growing media for ornamental plants and turf. UNSW Press Book. Sydney. Australia.

Hewitt, E.J. (1952). Sand and water culture methods used in the study of plant nutrition. Commonwealth Agricultural Bureaux. UK.

Kusmiba, P. (1994). The effect of growing media and foliar fertilisation to growth of salak seedlings in peat land (in Indonesian). J. Penel. UNTAN 4 (14), 25-33.

Kusumo, S. (1995). Salak, a prideful fruit of Indonesia. IARD Journal, 17 (2), 19-23.

Maier, H.G. (1990). Lebensmittel- und Umweltanalytik. Steinkopff Verlag, Darmstadt, Germany.

Marschner, H. (1995). Mineral nutrition of higher plants. $2^{\text {nd. }}$ ed.. Academic Press. CA, USA.

McGuire, R. (1992). Reporting of objective color measurements. Hort. Sci., 27, 1254-1255.

Ministry of Agriculture of Indonesia. (2009). [Online] Available: http://www.hortikultura.go.id/index.php?option=com_content\&task=view\&id=240\&itemid=1 (March 6, 2011).

Ministry of Agriculture of Indonesia. (2011). http://database.deptan.go.id/bdsp/hasil kom.asp (March 6, 2011).

Ochse, J.J. (1931). Fruits and fruitculture in the Dutch East Indies (English eds.). G. Kolff \& Co - Batavia, Indonesia.

Okoye, H.C. (1980). Plant analysis as an aid in the fertilization of the oil palm. FAO Soils Bulletin, 38 (1), 164-179.

Oliviera, M.A.J., Bovi, M.L.A., Machado, E.C., Gomes, M.M.A., Habermann, G. \& Rodrigues, J.D. (2002). Photosynthesis, stomatal conductance and transpiration in peach palm under water stress. Sci. Agric., (Piracicaba Braz.), 59, $59-63$.

Pinamonti, F. \& Sicher, L. (2000). Compost utilization in fruit production systems. In: Stoffella, P.J. and Kahn, B.A. (eds.). Compost utilization in horticultural cropping systems. Lewis Publishers, CRC Press LLC, Florida, USA. 
Ross, M. (1999). Auswirkungen verschiedener Rodeverfahren und des Unterbewuchses auf Bodenfruchtbarkeit, Bodenwasserhaushalt, Erosion und Bestandsentwicklung eines Ölpalmenbestandes. Dissertation. Humboldt Universität zu Berlin. Berlin, Germany.

Salisbury, F.B. \& Ross, C.W. (1985). Plant physiology. International Thompson Publishing, CA, USA.

Schimansky, C. (1981). Der Einfluss einiger Versuchparameter auf das Fluxverhalten von ${ }^{28} \mathrm{Mg}$ bei Gerstenkeimpflanzen in Hydrokulturversuchen. Landwirtsch. Forsch, 34, 154 -165

Schubert, S., Schubert, E. \& Mengel, K. (1990). Effect of low pH of the root medium on proton release, growth, and nutrient uptake of field beans (Vicia faba). Plant Soil, 124, 239-244. http://dx.doi.org/10.1007/BF00009266

Schuiling, D.L. \& Mogea, J.P. (1992). Salacca zalacca (Gaertner) Voss. In: Verheij, E.W.M. and Coronel, R.E. (eds.), Edible fruits and nuts, Plant Resources of South East Asia No. 2. PROSEA, Bogor, Indonesia, 247-248.

Steel, R.G.D., Torrie, J..H. \& Dickey, D. (1997). Principles and procedures of statistics. McGraw-Hill, New York, USA.

Sudaryono, T., Purnomo, S. \& Soleh, M. (1993). Cultivar distribution and estimation of area development of Salacca (in Indonesian). Penel. Hort., 5, 1-4.

Thomas, D.S. \& Turner, D.W. (2001). Banana (Musa sp.) leaf gas exchange and chlorophyll fluorescence in response to soil drought, shading and lamina folding. Sci. Hort., 90, 93-108. http://dx.doi.org/10.1016/S0304-4238(00)00260-0

Walsh, L.M. \& Murdoch, J.T. (1963). Recovery of fixed ammonium by corn in greenhouse studies. Soil Sci. Soc. Am. Proc., 27: 200-204. http://dx.doi.org/10.2136/sssaj1963.03615995002700020032x

Wetlands International. (2003). http://www.wetlands.or.id/PDF/Atlas\%2520Review.pdf (March 6, 2011).

Winarno, M. (1997). The policy on developing horticulture (in Indonesian). Panitia Dies Natalis ke-51. Fakultas Pertanian. Universitas Gadjah Mada. Yogyakarta, Indonesia.

Table 1. Leaf area increment (LAI) and shoot length increment (SLI) of different salak cultivars ("gading" (G), "pondoh super" (PS), "pondoh hitam" (PH) and "pondoh manggala" (PM))

\begin{tabular}{|l|c|c|c|c|}
\hline \multirow{2}{*}{ Growth parameter } & \multicolumn{4}{|c|}{ Cultivar } \\
\cline { 2 - 5 } & $\mathrm{G}$ & PS & PH & PM \\
\hline LAI $\left(\mathrm{cm}^{2}\right)$ & $213.3 \pm 17.4 \mathrm{a}$ & $240.8 \pm 7.9 \mathrm{a}$ & $288.2 \pm 15.7 \mathrm{~b}$ & $280.0 \pm 22.3 \mathrm{ab}$ \\
\hline SLI $(\mathrm{cm})$ & $44.98 \pm 1.19 \mathrm{a}$ & $41.09 \pm 2.21 \mathrm{a}$ & $49.89 \pm 2.28 \mathrm{a}$ & $43.38 \pm 3.01 \mathrm{a}$ \\
\hline
\end{tabular}

Values represent means \pm SE. Different letters in the same row indicate significant differences by LSD test $(\mathrm{P} \leq$ $0.05)$

Table 2. Leaf area increment (LAI) and shoot length increment (SLI) of salak seedlings growing in different media

\begin{tabular}{|l|l|l|l|}
\hline \multirow{2}{*}{ Growth parameter } & \multicolumn{3}{|c|}{ Growing medium } \\
\cline { 2 - 4 } & Sand & Peat & Sand/Compost \\
\hline LAI $\left(\mathrm{cm}^{2}\right)$ & $300.5 \pm 10.7 \mathrm{~b}$ & $264.9 \pm 10.2 \mathrm{~b}$ & $187.0 \pm 15.3 \mathrm{a}$ \\
\hline SLI $(\mathrm{cm})$ & $50.48 \pm 1.46 \mathrm{~b}$ & $44.46 \pm 1.86 \mathrm{ab}$ & $38.55 \pm 1.99 \mathrm{a}$ \\
\hline
\end{tabular}

Values represent means \pm SE. Different letters in the same row indicate significant differences by LSD test $(\mathrm{P} \leq$ $0.05)$ 
Table 3. Effect of salak cultivars ("gading" (G), "pondoh super" (PS), "pondoh hitam" (PH), "pondoh manggala" (PM)) and growing media on growth of salak seedlings

\begin{tabular}{|c|c|c|c|c|}
\hline \multirow[t]{2}{*}{ Growth parameter } & \multirow[t]{2}{*}{ Cultivar } & \multicolumn{3}{|c|}{ Growing Medium } \\
\hline & & Sand & Peat & Sand/Compost \\
\hline \multirow{4}{*}{ Root DW (g) } & $\mathrm{G}$ & $0.94+0.07 \mathrm{c}$ & $0.81+0.04 b c$ & $0.77+0.06 b c$ \\
\hline & PS & $0.86 \pm 0.06 \mathrm{bc}$ & $0.54 \pm 0.02 \mathrm{a}$ & $0.93 \pm 0.13 b c$ \\
\hline & $\mathrm{PH}$ & $1.11 \pm 0.11 \mathrm{c}$ & $0.82 \pm 0.13 a b c$ & $1.00 \pm 0.09 \mathrm{c}$ \\
\hline & PM & $0.96 \pm 0.07 \mathrm{c}$ & $0.70 \pm 0.04 \mathrm{~b}$ & $0.83 \pm 0.10 \mathrm{bc}$ \\
\hline \multirow[t]{4}{*}{ Shoot DW (g) } & $\mathrm{G}$ & $3.56 \pm 0.22 b c$ & $3.43 \pm 0.15 b c$ & $3.14 \pm 0.08 \mathrm{~b}$ \\
\hline & PS & $3.26+0.17 b c$ & $2.55+0.11 \mathrm{a}$ & $3.79 \pm 0.49 \mathrm{bcd}$ \\
\hline & $\mathrm{PH}$ & $4.68 \pm 0.20 \mathrm{~d}$ & $4.28 \pm 0.43 \mathrm{~cd}$ & $4.15 \pm 0.22 \mathrm{~cd}$ \\
\hline & PM & $3.97 \pm 0.23 \mathrm{~cd}$ & $3.69 \pm 0.08 \mathrm{c}$ & $3.12 \pm 0.17 \mathrm{~b}$ \\
\hline \multirow[t]{4}{*}{ Shoot/Root } & $\mathrm{G}$ & $3.94+0.39 \mathrm{ab}$ & $4.25+0.16 \quad \mathrm{ab}$ & $4.16 \pm 0.22 \mathrm{ab}$ \\
\hline & PS & $3.83 \pm 0.23 \mathrm{a}$ & $4.74 \pm 0.23 \mathrm{~b}$ & $4.16 \pm 0.25 \mathrm{ab}$ \\
\hline & $\mathrm{PH}$ & $4.39+0.25 \mathrm{ab}$ & $5.37 \pm 0.38 b$ & $4.28+0.33 \mathrm{ab}$ \\
\hline & PM & $4.23+0.27 \mathrm{ab}$ & $5.31+0.22 b$ & $3.85+0.34 \mathrm{ab}$ \\
\hline \multirow[t]{4}{*}{ LAI $\left(\mathrm{cm}^{2}\right)$} & G & $272.9 \pm 17.7 \mathrm{c}$ & $242.2 \pm 15.1 b c$ & $124.9 \pm 20.9 \mathrm{a}$ \\
\hline & PS & $259.9 \pm 12.1 \mathrm{bc}$ & $219.9+12.8 b$ & $243.0+12.7 b c$ \\
\hline & $\mathrm{PH}$ & $325.4 \pm 13.9 \mathrm{c}$ & $324.0 \pm 15.3 \mathrm{c}$ & $230.5 \pm 25.2 \mathrm{bc}$ \\
\hline & $\mathrm{PM}$ & $343.8+24.1 \mathrm{c}$ & $298.9+8.69 c$ & $135.3+28.5 \mathrm{a}$ \\
\hline \multirow[t]{4}{*}{ SLI $(\mathrm{cm})$} & G & $45.70 \pm 2.50 \mathrm{~cd}$ & $45.86 \pm 1.18 \mathrm{c}$ & $43.37 \pm 2.42 \mathrm{c}$ \\
\hline & PS & $49.11 \pm 2.12 \mathrm{~cd}$ & $37.34 \pm 3.46 \mathrm{bc}$ & $36.10 \pm 3.95 b$ \\
\hline & $\mathrm{PH}$ & $55.34 \pm 2.55 \mathrm{~d}$ & $51.85 \pm 4.32 \mathrm{bcd}$ & $43.33 \pm 3.69 \mathrm{a}$ \\
\hline & PM & $51.74 \pm 3.55 \mathrm{~cd}$ & $45.97 \pm 4.04 \mathrm{bcd}$ & $28.04 \pm 2.96 \mathrm{ab}$ \\
\hline
\end{tabular}

$\mathrm{DW}=$ Dry weight, $\mathrm{LAI}=$ Leaf area increment, $\mathrm{SLI}=$ Shoot length increment

Values represent means \pm SE. Different letters in the same parameter indicate significant differences by LSD test $(\mathrm{P} \leq 0.05)$

Table 4. Effect of salak cultivars ("gading" (G), "pondoh super" (PS), "pondoh hitam" (PH), "pondoh manggala" $(\mathrm{PM})$ ) and growing media on net $\mathrm{CO}_{2}$ assimilation rate $\left(\mathrm{P}_{\mathrm{N}}\right)$ of salak seedlings on week 6, 8 and 13 after transplanting

\begin{tabular}{|c|c|c|c|c|}
\hline \multirow{2}{*}{$\begin{array}{c}\mathrm{P}_{\mathrm{N}} \\
\left(\mu \mathrm{mol} \mathrm{CO} \mathrm{CO}_{2} \mathrm{~m}^{-2} \mathrm{~s}^{-1}\right)\end{array}$} & \multirow[t]{2}{*}{ Cultivar } & \multicolumn{3}{|c|}{ Growing Medium } \\
\hline & & Sand & Peat & Sand/Compost \\
\hline \multirow[t]{4}{*}{ Week 6} & $\mathrm{G}$ & $2.95 \pm 0.11 \mathrm{c}$ & $3.60 \pm 0.32 \mathrm{c}$ & $2.13 \pm 0.65 \mathrm{abc}$ \\
\hline & PS & $1.50 \pm 0.25 \mathrm{ab}$ & $1.40 \pm 0.38 \mathrm{ab}$ & $1.92 \pm 0.26 \mathrm{~b}$ \\
\hline & $\mathrm{PH}$ & $1.33 \pm 0.47 \mathrm{ab}$ & $2.57 \pm 0.53 b c$ & $2.20 \pm 0.28 b c$ \\
\hline & PM & $1.37 \pm 0.37 \mathrm{ab}$ & $0.75 \pm 0.19 \mathrm{a}$ & $1.77 \pm 0.20 \mathrm{~b}$ \\
\hline \multirow[t]{4}{*}{ Week 8} & G & $2.27 \pm 0.47 \mathrm{ab}$ & $3.15 \pm 0.28 b$ & $1.75 \pm 0.38 \mathrm{ab}$ \\
\hline & PS & $1.52 \pm 0.30 \mathrm{ab}$ & $3.05 \pm 0.43 b c$ & $1.34+0.28 \mathrm{ab}$ \\
\hline & $\mathrm{PH}$ & $0.73 \pm 0.52 \mathrm{a}$ & $4.12 \pm 0.21 \mathrm{c}$ & $2.77 \pm 0.42 \mathrm{~b}$ \\
\hline & PM & $2.05 \pm 0.41 \mathrm{ab}$ & $2.23 \pm 0.27 \mathrm{ab}$ & $3.25 \pm 0.21 \mathrm{~b}$ \\
\hline \multirow[t]{4}{*}{ Week 13} & $\mathrm{G}$ & $2.88 \pm 0.29 \mathrm{ab}$ & $3.75 \pm 0.46 \mathrm{abc}$ & $4.38 \pm 0.48 \mathrm{~b}$ \\
\hline & PS & $2.16 \pm 0.37 \mathrm{a}$ & $2.55 \pm 0.42 \mathrm{a}$ & $3.47 \pm 0.55 \mathrm{abc}$ \\
\hline & $\mathrm{PH}$ & $3.60 \pm 0.41 \mathrm{abc}$ & $2.12 \pm 0.63 \mathrm{a}$ & $4.48 \pm 0.20 \mathrm{c}$ \\
\hline & $\mathrm{PM}$ & $3.42 \pm 0.35 \mathrm{abc}$ & $3.25 \pm 0.40 \mathrm{ab}$ & $2.13 \pm 0.18 \mathrm{a}$ \\
\hline
\end{tabular}

Values represent means \pm SE. Different letters in the same parameter data indicate significant differences by LSD test $(\mathrm{P} \leq 0.05)$ 
Table 5. Colour parameters ( $\mathrm{L}^{*}, \mathrm{a}^{*}, \mathrm{~b}^{*}$, chroma and hue angle) in leaves of different salak cultivars ("gading", "pondoh super", "pondoh hitam" and "pondoh manggala")

\begin{tabular}{|l|l|l|l|l|}
\hline \multirow{2}{*}{ Colour parameters } & \multicolumn{5}{|c|}{ Cultivar } \\
\cline { 2 - 5 } & "gading" & "pondoh super" "pondoh hitam" & "pondoh manggala" \\
\hline L*-value & $37.41 \pm 0.93 \mathrm{a} *$ & $37.81 \pm 0.70 \mathrm{a}$ & $36.97 \pm 0.63 \mathrm{a}$ & $37.90 \pm 0.58 \mathrm{a}$ \\
\hline $\mathrm{a} *$ - value & $-13.73 \pm 0.52 \mathrm{a}$ & $-14.24 \pm 0.53 \mathrm{a}$ & $-13.15 \pm 0.54 \mathrm{a}$ & $-14.46 \pm 0.39 \mathrm{a}$ \\
\hline $\mathrm{b} *$ - value & $17.22 \pm 1.23 \mathrm{a}$ & $18.01 \pm 1.12 \mathrm{a}$ & $16.37 \pm 0.98 \mathrm{a}$ & $18.33 \pm 0.69 \mathrm{a}$ \\
\hline Chroma & $22.05 \pm 1.29 \mathrm{a}$ & $22.98+1.20 \mathrm{a}$ & $21.01+1.11 \mathrm{a}$ & $23.36+0.76 \mathrm{a}$ \\
\hline Hue angle & $129.11 \pm 0.87 \mathrm{a}$ & $128.70+0.70 \mathrm{a}$ & $129.11+0.57 \mathrm{a}$ & $128.41+0.58 \mathrm{a}$ \\
\hline
\end{tabular}

Values represent means \pm SE. Different letters in the same row indicate significant differences by LSD test $(\mathrm{P} \leq 0.05)$

Table 6. Colour parameters $\left(\mathrm{L}^{*}, \mathrm{a}^{*}, \mathrm{~b}^{*}\right.$, chroma and hue angle) in leaves of salak seedlings growing in different media

\begin{tabular}{|c|c|c|c|}
\hline \multirow{2}{*}{ Colour parameters } & \multicolumn{3}{|c|}{ Growing medium } \\
\cline { 2 - 4 } & Sand & Peat & Sand/Compost \\
\hline $\mathrm{L}^{*}$ - value & $35.73 \pm 0.33 \mathrm{a}^{*}$ & $39.73 \pm 0.60 \quad \mathrm{~b}$ & $37.11 \pm 0.40 \mathrm{a}$ \\
\hline $\mathrm{a}^{*}$ - value & $-13.05 \pm 0.35 \mathrm{~b}$ & $-15.26 \pm 0.37 \mathrm{a}$ & $-13.37 \pm 0.40 \mathrm{~b}$ \\
\hline $\mathrm{b}^{*}$ - value & $15.69 \pm 0.60 \mathrm{a}$ & $20.47 \pm 0.82 \quad \mathrm{~b}$ & $16.28 \pm 0.70 \mathrm{a}$ \\
\hline Chroma & $20.42 \pm 0.68 \mathrm{a}$ & $25.55 \pm 0.87 \quad \mathrm{~b}$ & $21.08 \pm 0.78 \mathrm{a}$ \\
\hline Hue angle & $129.93 \pm 0.38 \mathrm{~b}$ & $126.95 \pm 0.54 \mathrm{a}$ & $129.61 \pm 0.51 \mathrm{~b}$ \\
\hline
\end{tabular}

Values represent means \pm SE. Different letters in the same row indicate significant differences by LSD test $(\mathrm{P} \leq 0.05)$

Table 7. Mineral contents of salak seedlings growing in different media

\begin{tabular}{|l|l|l|l|l|l|c|}
\hline Growing media & $\mathrm{N}(\mathrm{mg} / \mathrm{g})$ & $\mathrm{P}(\mathrm{mg} / \mathrm{g})$ & $\mathrm{K}(\mathrm{mg} / \mathrm{g})$ & $\mathrm{Mg}(\mathrm{mg} / \mathrm{g})$ & $\mathrm{Ca}(\mathrm{mg} / \mathrm{g})$ & $\Sigma$ \\
\hline Sand & $44.18 \pm 1.7 \mathrm{~b}$ & $3.69 \pm 0.1 \mathrm{~b}$ & $8.96 \pm 0.3 \mathrm{a}$ & $1.88 \pm 0.1 \mathrm{a}$ & $6.10 \pm 0.2 \mathrm{a}$ & 64.81 \\
\hline Peat & $44.76 \pm 1.0 \mathrm{~b}$ & $6.86 \pm 0.2 \mathrm{c}$ & $11.83 \pm 0.2 \mathrm{~b}$ & $3.70 \pm 0.5 \mathrm{~b}$ & $7.65 \pm 0.3 \mathrm{ab}$ & 74.80 \\
\hline Sand/Compost & $32.45 \pm 1.6 \mathrm{a}$ & $2.48 \pm 0.1 \mathrm{a}$ & $14.37 \pm 0.6 \mathrm{c}$ & $1.44 \pm 0.1 \mathrm{a}$ & $9.48 \pm 0.7 \mathrm{~b}$ & 60.22 \\
\hline
\end{tabular}

Values represent means \pm SE. Different letters in the same column indicate significant differences by LSD test $(\mathrm{P} \leq 0.05)$

Optimal range for plant growth according to Marschner (1995) as follows (in $\mathrm{mg} / \mathrm{g}$ ):

$\mathrm{N}=20-50 \quad \mathrm{P}=3-5 \quad \mathrm{~K}=<20-50 \quad \mathrm{Mg}=1.5-3.5 \quad \mathrm{Ca}=1->50$ 


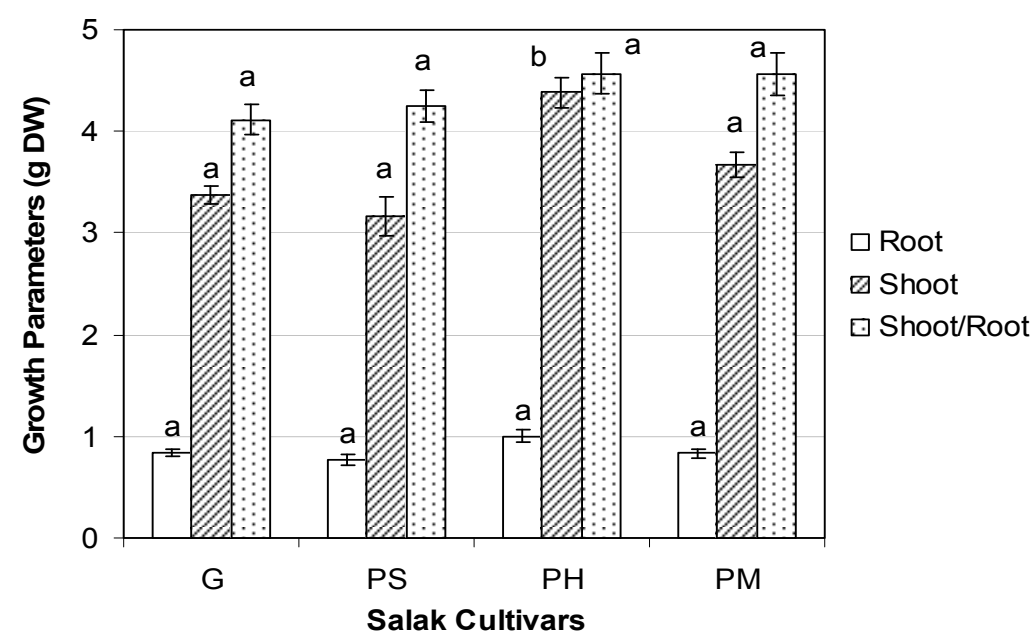

Figure 1. Root and shoot dry weight and shoot/root ratio of different salak cultivars ("gading" (G), "pondoh super" (PS), "pondoh hitam" (PH) and "pondoh manggala" (PM)). Different letters in the same parameter indicate significant differences by LSD test $(\mathrm{P} \leq 0.05)$

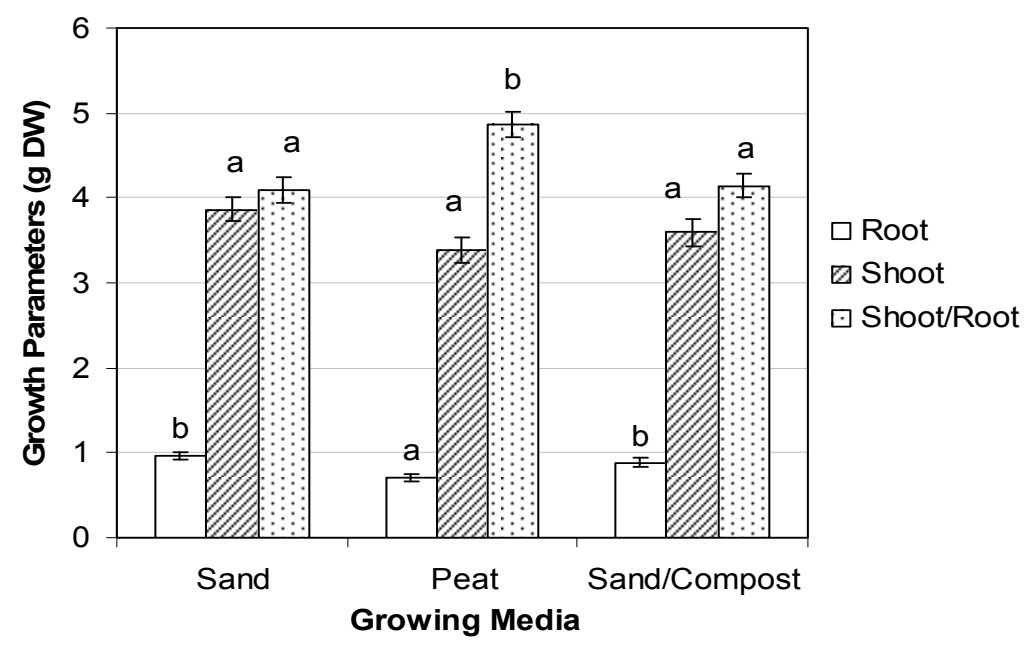

Figure 2. Root and shoot dry weight and shoot/root ratio salak seedlings growing in different media. Different letters in the same parameter indicate significant differences by LSD test $(\mathrm{P} \leq 0.05)$

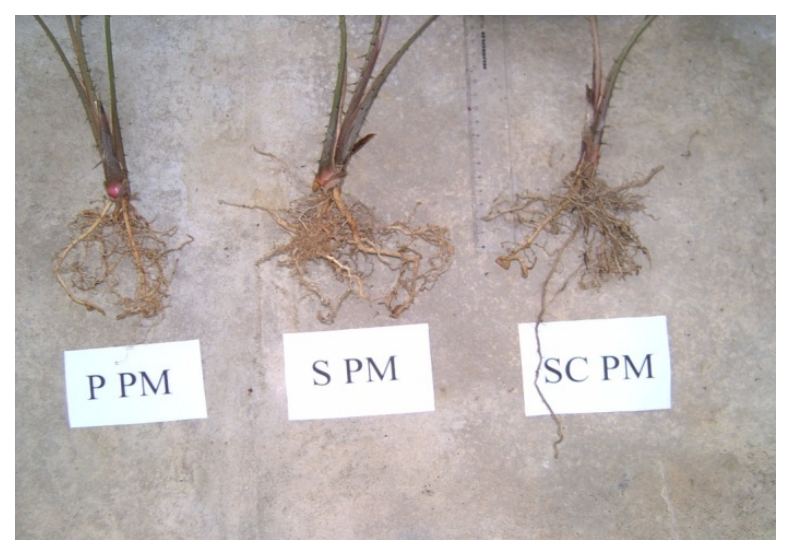

Figure 3. Root growth of salak "pondoh manggala" (PM) seedlings in different growing media (peat (P), sand (S), sand/compost (SC)) 


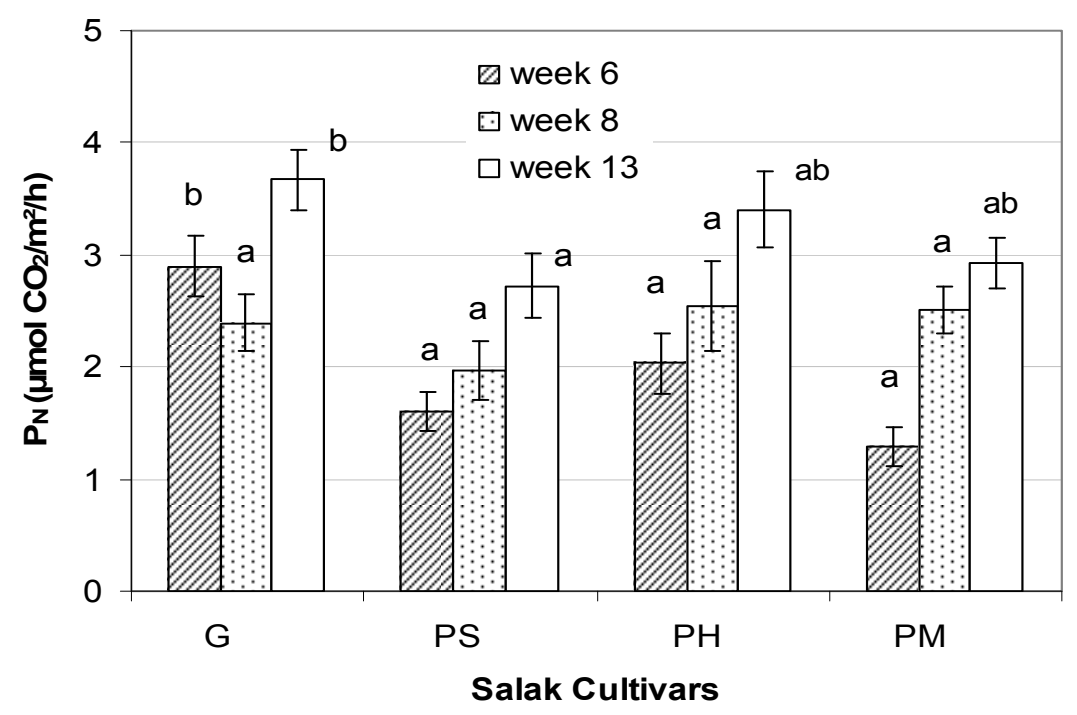

Figure 4. Net $\mathrm{CO}_{2}$ assimilation rate $\left(\mathrm{P}_{\mathrm{N}}\right)$ of different salak cultivars, "gading" $(\mathrm{G})$, "pondoh super" (PS), "pondoh hitam" (PH) and "pondoh manggala" (PM) at week 6, 8 and 13 after transplanting. Different letters in the same parameter indicate significant differences by LSD test $(\mathrm{P} \leq 0.05)$

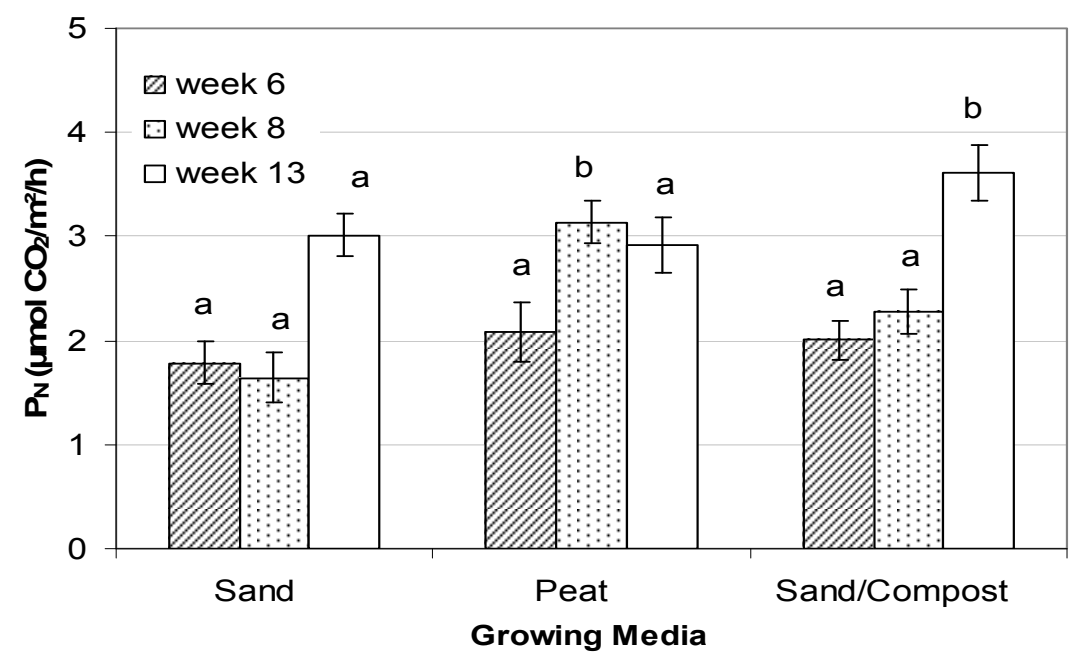

Figure 5. Net $\mathrm{CO}_{2}$ assimilation rate $\left(\mathrm{P}_{\mathrm{N}}\right)$ of salak seedlings growing in different media at week 6,8 and 13 after transplanting. Different letters in the same parameter indicate significant differences by LSD test $(\mathrm{P} \leq 0.05)$ 